\title{
An Integrated Approach to Flood Risk Management: A Case Study of Navaluenga (Central Spain)
}

\author{
J. A. Ballesteros-Cánovas • M. Sanchez-Silva • \\ J. M. Bodoque • A. Díez-Herrero
}

Received: 14 September 2011 / Accepted: 18 March 2013 /

Published online: 16 April 2013

(C) Springer Science+Business Media Dordrecht 2013

\begin{abstract}
Flood risk management decisions require the rational assessment of mitigation strategies. This is a complex decision-making process involving many uncertainties. This paper presents a case study where a cost-benefit based methodology is used to define the best intervention measures for flood-risk mitigation in central Spain. Based on different flood hazard scenarios, several structural measures considered by the local Basin Water Authority and others defined by engineering criteria were checked for operability. Non-systematic data derived from dendrogeomorphological analysis of riparian trees were included in the flood frequency analysis. Flood damage was assessed by means of depth-damage functions, and flooded urban areas were obtained by applying a hydraulic model. The best defense strategies were obtained by a cost-benefit procedure, where uncertainties derived from each analytical process were incorporated based on a stochastic approach to estimate expected economic losses. The results showed that large structural solutions are not economically viable when compared with other smaller structural measures, presumably because of the pre-established location of dams in the upper part of the basin which do not laminate the flow generated by the surrounding catchment to Navaluenga.
\end{abstract}

Keywords Flood risk · Hydrological model $\cdot$ Hydraulic model $\cdot$ Flood damages · Uncertainties · Tree-rings $\cdot$ Navaluenga

J. A. Ballesteros-Cánovas $(\bowtie)$

Laboratory for Dendrogeomorphology, Institute of Geological Sciences, University of Berne, Baltzerstrasse 1-3, Berne 3012, Switzerland

e-mail: juan.ballesteros@dendrolab.ch

M. Sanchez-Silva

Department of Civil and Environmental Engineering, Universidad de Los Andes, Bogotá, Colombia

J. M. Bodoque

Mining and Geological Engineering Department, University of Castilla-La Mancha, Campus Fábrica de Armas, Avda. Carlos III, Toledo 45071, Spain

A. Díez-Herrero

Department of Research and Geoscientific Prospective, Geological Survey of Spain (IGME), Ríos Rosas 23, Madrid 28003, Spain 


\section{Introduction}

Every year, flooding causes important economic damage and loss of life worldwide (Gaume et al. 2009). Recent studies indicate that catastrophic flood events have increased over the last 10 years in Europe, with a large number of casualties and losses amounting to more than 100 billion euros between 1986 and 2006 (CEA 2007). In the case of the Iberian Peninsula, the different scenarios reported by the IPCC (IPCC 2001), as a result of increased greenhouse gases and aerosol concentrations, indicate that the likelihood of increased rainfall may pose major flood risks in the future (Pall et al. 2011). Furthermore, it has been suggested that inadequate land-use policies, together with major human activity on flood plains, could increase flood damage as a result of higher exposure and vulnerability (Benito 2006). In Spain alone, the expected economic losses for the period 2004-2033 could reach almost $€ 24$ billion (Ferrer et al. 2004) with an unknown but large number of casualties. Within this context, defining optimum strategies for appropriate flood risk management, as specified in the EU Flood Directive 2007/60/EC, is of paramount importance.

Flood risk management aims to reduce damage to people and goods to acceptable levels (Loucks et al. 2008). Risk management strategies require both structural and non-structural measures and must be designed according to the type of flooding and the associated flood risk (Plate 2002). Furthermore, optimal decisions must be based on a cost-benefit analysis (CBA) of the different alternatives for risk mitigation (Zhu and Lund 2009). CBA aims to optimize the choice of alternatives from a financial standpoint (Tung 2002). This procedure has been extensively used in many engineering fields (Sánchez-Silva 2001) including structural flood defenses (Tung and Mays 1981; Plate 2000), as well as the complete basin defense plans for different likely scenarios (Dutta et al. 2006; Rasekh, et al. 2010; Eum et al. 2012). Flood risk management based on CBA allows assertive decision-making, which is essential for building a safer society (Rackwitz et al. 2005).

Because of the large number of parameters involved in flood risk analysis and their uncertainty, it is essential to rethink existing deterministically-based decision models (Apel et al. 2004; Merz et al. 2010). Uncertainty is mainly due to the variability of input data (irreducible uncertainty) and an insufficient understanding of flood processes (reducible uncertainty; Merz et al. 2002). For instance, Apel et al. (2004) classified the types of uncertainty existing in flood risk analysis and applied a stochastic model based on recorded data (i.e. flow gauge). Faber (2006) managed variability from hydrometeorological records and hydraulic models with Monte Carlo simulations to assess different operational flood scenarios at two study sites. Neuhold et al. (2009) described the variability observed due to changes in river bed morphology based on deterministic models and applied it to flood risk assessment. In all cases, the scientific community agrees on the difficulty of describing all the uncertainties involved in the flood risk assessment process. Thus, optimal decisions can only be made by taking into consideration all relevant uncertainties. Nevertheless, due to the predominance of extreme value statistics in uncertainty analysis it is essential in flood risk assessment to search for and include reliable evidence to improve statistical characterization (Merz et al. 2002). An important component of the process of constructing dependable models is the collection and management of experimental data to implement stochastic hydrological and hydraulic models. One possible way of extending systematic records is to include non-systematic data in flood analysis (Benito et al. 2005; Baker 2008). This may include dating sedimentary deposits by past floods and written records (Benito and Thorndycraft 2004), as well as tree-ring evidence (Ballesteros et al. 2011a) as useful proxy data to reconstruct past flood events and therefore to explore variability and improve understanding of this process. 
The aim of this paper is to present an integrated approach to evaluate a set of feasible local flood defenses based on flood risk analysis. An important contribution here is that the analysis uses non-systematic data derived from riparian vegetation. A stochastic approach is used here to manage the variability derived from non-systematic data from tree-ring analysis (Ballesteros et al. 2011b) with the results derived from deterministic hydrological and hydraulic procedures. Other sources of reducible uncertainties (i.e. different storage capacity of dams; bottom outlet operativity; variability in flood depth-damage curves) have also been considered. Finally, a case study is presented of the Alberche river passing through the village of Navaluenga (Spanish Central System).

\section{Overall Methodological Description and Model Used}

The proposed approach quantifies the expected flood risk derived from various flood defense alternatives. It takes into account uncertainties resulting from non-systematic data included in hazard analysis. The conceptual framework is shown in Fig. 1. Flood risk is evaluated in terms of the expected annual flood damage, expressed as: $E(D \mid x)$, where $D$ is the damage caused by a specific flood event $(x)$ in a specific location (Tung 2002). Epistemic uncertainties have been included following the guidelines reported by Merz et al. (2002).

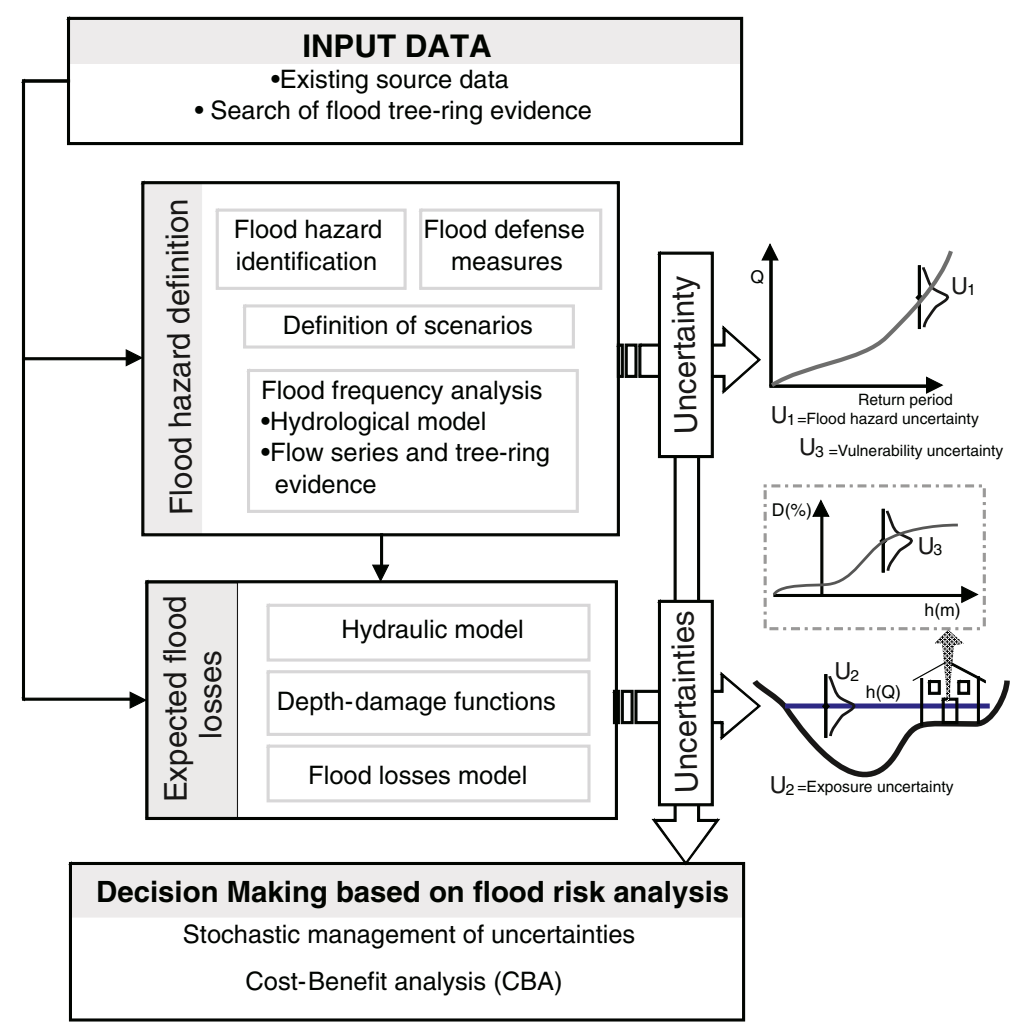

Fig. 1 Methodological diagram used in flood risk estimate and decision-making process for different flood defense alternatives 
A cost analysis of various flood prevention structural measures was carried out for each scenario. These structural measures include large and smaller dams as well as a set of storm tanks (CHT 1992). Based on rainfall data, a semi-distributed hydrological model (HEC-HMS) was implemented to calculate the Flood Frequency Curve function (USACE 2009). This model allows the use of several techniques to set up and control variables for simulating a rainfall-runoff process as well as the outcome of defense measures (i.e. reservoirs) in the basin system.

Empirical flood depth-damage curves were used to evaluate the economic losses for each return period (USACE 1992, and PATRICOVA 2002). The 1D/2D coupled numerical hydrodynamic flow model MIKE FLOOD (DHI 2008) was used to obtain the water depth. This model is based on numerical equations of conservation of mass/momentum (Chow 1959) and is run with the required input data and parametrization including bathymetry and topography of the floodplain, geometry of hydraulic infrastructures, roughness value, eddy viscosity parameter, computational time step and boundary conditions.

Finally a cost-based analysis was carried out to estimate the expected cost of each defense alternative considered (Section 4.4; Tung 2002). Although similar decision-based risk approaches have been proposed and used (Merz et al. 2002; Tung 2002; Faber 2006; Dietrich et al. 2009), as far as the authors are aware this is one of the first examples of applied flood risk analysis where evidence from past flood tree-rings (i.e. non-systematic data) has been included in a flood hazard definition.

\section{Case Study: Navaluenga, Spain}

\subsection{Basin System Description}

The village of Navaluenga is located in the south of the province of Avila between the Sierra del Valle (E. Sierra de Gredos) and the Sierra de la Paramera (40 $24^{\prime} 30^{\prime \prime} \mathrm{N} ; 4^{\circ} 42^{\prime} 17^{\prime \prime} \mathrm{W}$; $761 \mathrm{~m}$ asl; Fig. 2). This is one of most important villages within the unregulated basin of the Alberche river. The year-round population is 2011 inhabitants, with average age 47, which may reach a total population of 20,000 during the summer period. The provincial GDP is $€ 19,940$. The urban area is approx. $74 \mathrm{~km}^{2}$ with over 4300 houses.

The Alberche river flows W-E through the village and its tributary, the Chorrerón, flows N-S (Fig. 2a). The archaeological heritage of the village includes a Roman bridge. Before reaching the village, the Alberche flows for $70 \mathrm{~km}$ in a natural regime with an average slope of $0.02 \mathrm{~m} / \mathrm{m}$, forming a river basin area of $717 \mathrm{~km}^{2}$. The basin is situated on impermeable bedrock materials of the Variscan Massif i.e., granitoids, schist and migmatite (Orejana et al. 2009) generating thin soils with high runoff potential. This area is characterized by a strongly continentalized Mediterranean climate (mean $T=14{ }^{\circ} \mathrm{C}$; rainfall $=400-1200 \mathrm{~mm}$ ) with forest cover and with grassland, scrub and agricultural soils.

A series of hydrometeorological gauges is located within the basin system, including 18 rainfall gauges with a 65 -year validity period and a flow gauge operative since 1973/74 to the present, recording an average daily discharge of $133 \mathrm{~m}^{3} \mathrm{~s}^{-1} / 24 \mathrm{~h}$, ranging from 522.4 $\mathrm{m}^{3} \mathrm{~s}^{-1} / 24 \mathrm{~h}-15.4 \mathrm{~m}^{3} \mathrm{~s}^{-1} / 24 \mathrm{~h}$ (CHT 2012). Evidence of past flood events has also been found on riverbank trees on the flood plain (Ballesteros et al. 2011b, Fig. 2b).

\subsection{Flood Damage: Historical Evidence}

The analysis was based on both historical information collected from recorded flood occurrences and previous field observation. Flood evidence was obtained from people living locally 


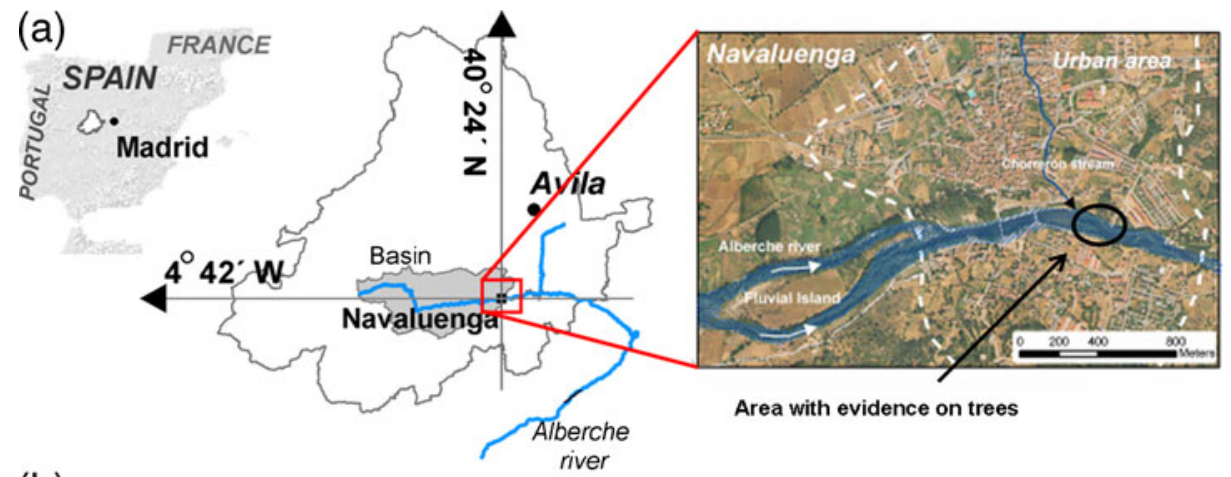

(b)
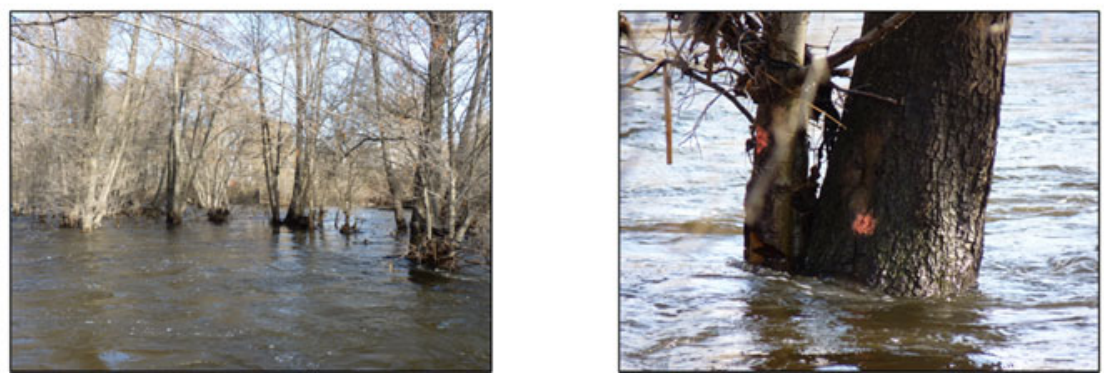

Fig. 2 a The River Alberche is located in the Iberian Central System, in the south of the province of Avila, Spain. b The trees affected by flooding in the study area present dendrogeomorphic evidence including stem scars, enabling estimates of past flood events (Ballesteros et al. 2011b)

who have experienced flooding and described the consequences. The oldest reliable documented records date from 1485, with more historical events recorded in the 18th and 19th centuries $(1733,1739,1747,1756,1789$ and 1856). More than 40 mentions of flooding are found in the local and regional press over the last 140 years. These historical floods and their consequences are described by other authors (Díez 2001).

Flood events of different magnitudes affecting Navaleunga have been observed e.g. the 1989 flood event (with peak discharge of $1099 \mathrm{~m}^{3} \mathrm{~s}^{-1}$ ), causing damage and financial losses to housing and commercial facilities. Another example is the flood during the summer of 2009, which caused considerable damage to the ecosystem and to the water supply system, resulting in a domestic water shortage.

Data analysis shows that damage may have occurred as the result of the following:

i) flooding of the floodplains of both the main channel and its tributary stream, delimited by a geomorphologic approach;

ii) deficiency of the levees built to accommodate discharges associated with medium-high return periods;

iii) possible backwater effects upstream, aggravated by the existence of the historical and modern arch bridges;

iv) the impact of the backwater effect caused by the coalescence of flood events in the Alberche and Chorreron.

Based on these results, two scenarios were considered:

- $\quad$ S1) flooding occurring only in the Alberche;

- $\quad$ S2) coalescing floods in the Alberche and the Chorrerón. 


\subsection{Structural Mitigation Alternatives}

The alternatives considered to decrease the peak of the expected hydrograph at Navaluenga were:

a) Large dams: the construction of up to three large dams previously proposed by the local water authority (Confederación Hidrográfica del Tajo) (CHT 1992) at basin level design was considered. Various heights, hypothetical initial storage capacities and operativity of bottom outlets of the dams (i.e. open outlets vs. closed outlets) were evaluated.

b) Small dams (S-Dams): these are smaller masonry dams built in tributary streams. Two possible dike heights were considered.

c) Tributary stream storm tank (Chorrerón): constructing a storage tank to capture and retain rainwater during intense rainfall.

The locations of all mitigation structures considered are shown in Fig. 3a and Table. 1.

The construction and operational costs of each strategy were estimated using the following criteria:

i) average cost $/ \mathrm{m}^{3}$ concrete for large dams by type in Spain (per planned type: i.e. vault dams: $€ 2300 / \mathrm{m}^{3}$; gravity dams: $€ 600 / \mathrm{m}^{3}$; (MMA 2008));

ii) unit cost of work stipulated by the GTAGU (2010), for S-Dams $\left(\sim € 160 / \mathrm{m}^{3}\right)$ and storm tanks (€200,000/unit). Cleaning and maintenance costs for S-Dams and storm tanks were also considered (averaging $€ 150,000 / 25$ years for S-Dams and $€ 20,000 / 10$ years for storm tanks).

\section{Assessment of the Flood Risk}

\subsection{Hydrologic Model}

The hydrologic response was modeled based on data stored in 18 rain gauges installed within the basin and in its surroundings. Double-mass analysis (Kohler 1949; Searcy and Hardison 1960; Chang and Lee 1974) was used to check consistency between different
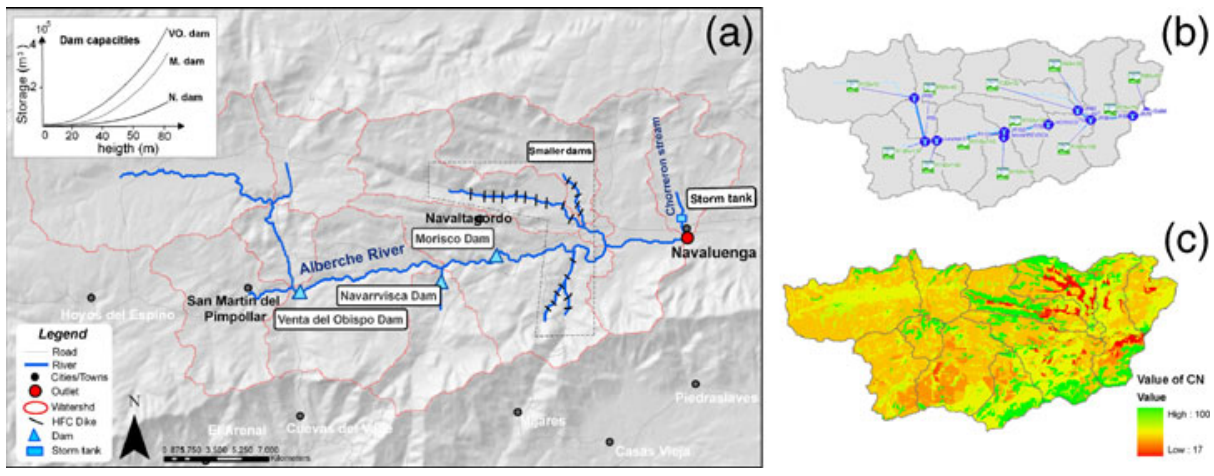

Fig. 3 a Schematic and spatial location of different alternatives considered for flood risk mitigation within the hydrological system. b Basin desegregation and scheme of the hydrologic model used. c Curve Number Values calculated in the study basin 
Table 1 Summary of the main technical characteristics of the structures measured. (*) N.B. Average characteristics given for smaller dams. Outlet discharge is computed as: $Q_{O U T}=C_{d} A \sqrt{(2 g h)}$, where Cd is discharge coefficient, $A$ outlet area, $g$ gravity and $h$ difference in height between water surface and outlet

\begin{tabular}{llllll}
\hline Structural measures & Typology & Height $(\mathrm{m})$ & Width (m) & $\begin{array}{l}\text { Live storage } \\
\text { capacity }\left(\mathrm{hm}^{3}\right)\end{array}$ & $\begin{array}{l}\text { Max. Outlet } \\
\text { Capacity }\left(\mathrm{m}^{3} \mathrm{~s}^{-1}\right)\end{array}$ \\
\hline Venta Obispo dam & Arch & $70-40$ & 300 & 176.7 & $\sim 200$ \\
Navarrevisca dam & Gravity & $50-20$ & 150 & 2.9 & $\sim 100$ \\
Morisco dam & Arch & $60-30$ & 350 & 45.2 & $\sim 1751$ \\
Smaller dams* & Gravity & 12 or 6 & $\sim 80$ & $\sim 0.25$ & $\sim 20$ \\
Storm tank & - & 5 & $4 \times 6$ & 0.00007 & $\sim 7$ \\
\hline
\end{tabular}

precipitation time series. Precipitation return periods were derived from the statistical analysis of the daily rainfall datasets, applying the two-parameter SQRT-exponential type distribution of maximum (SQRT-ET-max distribution), where the parameters are obtained by using maximum likelihood estimators. Because sub-daily rainfall data is not available at the study site, return periods of daily rainfall were disaggregated considering an hourly time step based on the official Spanish IDF curves and using the alternating blocks method (Chow et al. 1988) to obtain the design hyetograph.

To build the basin model, a 90 m Digital Elevation Model (DEM) was used. The level of stream network detail was defined considering $1 \%$ of the total drainage area as the upstream drainage area threshold (in square units) and consisted of 17 sub-basins (Fig. 3b). Disaggregation was based on the spatial distribution of the physiographic factors that determine a homogenous hydrologic response (i.e., lithology, cover type, hydrologic condition, and slope).

The curve number method $(\mathrm{CN})$ applied to determine losses were based on land use, land cover type and hydrologic soil group (Fig. 3c). The input data used to define the curve number grid was a digital forest map (scale 1/50,000), with an attribute table containing land-use information. Since there are no soil maps for Spain with the level of detail required in this study, the information about the hydrologic soil group had to be inferred from geomorphologic information combined with geological bands (scale 1:50,000). Flood risk reduction strategies in the system, including reservoirs, were modeled in the hydrologic model. Thus, stage-storage relationships for each reservoir were derived from a $5 \mathrm{~m} \mathrm{DEM}$, which is the most detailed topographic data available for the study site. According to the seasonal variability in central Spain, two initial water storage capacities were taken as boundary conditions (i.e. $100 \%$ and $30 \%$ ), but different dam heights and the operativity of bottom outlets were also considered.

The hydrologic model calibration and validation was limited by the short time series and the lack of information from hydrographs and hyetographs. Three events were used to compare the results, while two more were used to validate the model by means of an automatic calibration routine in which the percentage error in peak discharge and the unvaried method (Huberlandt et al. 2008) were used as the objective function and the search algorithm, respectively. The mean deviation derived from the calibration process was quantified as $23.3 \%$ (Table 2). Finally, the peak discharge results obtained were then fitted to the General Extreme Value (GEV) distribution:

$$
F_{H}(t ; \mu, \beta, \xi)=\exp \left\{-\left[1+\xi\left(\frac{t-\mu}{\beta}\right)^{\frac{-1}{\xi}}\right]\right.
$$


Table 2 Deviation values obtained between observed and simulated peak discharge after calibration of the hydrological model (validation events highlighted in grey)

\begin{tabular}{lccl}
\hline $\begin{array}{l}\text { Flood event } \\
\text { (Validation/ } \\
\text { Calibration) }\end{array}$ & $\begin{array}{l}\text { Observed peak } \\
\text { discharge (m3/s) }\end{array}$ & $\begin{array}{l}\text { Simulated peak } \\
\text { discharge (m3/s) }\end{array}$ & $\begin{array}{l}\text { Relative } \\
\text { deviation (\%) }\end{array}$ \\
\hline 2002 & 478 & 397 & 16.9 \\
1996 & 730 & 531 & 27.2 \\
1993 & 792 & 873 & 10.2 \\
2000 & 532 & 689 & 29.5 \\
1989 & 1186 & 797 & 32.7 \\
Total & & & $23.3 \%$ \\
\hline
\end{tabular}

where $\mu, \beta$ and $\varepsilon$ are parameters that can be estimated by the moment method. The Kolmogorov-Smirnoff test was also used to determine goodness of fit. Table 3 shows the

Table 3 Statistical parameters obtained during peak discharge fitted to the GEV function for each alternative. (*) Dam variability refers to observed variability in the GEV function derived from considering different storage capacity and existing dam outlets

\begin{tabular}{|c|c|c|c|c|c|c|c|c|c|}
\hline \multirow[t]{3}{*}{ Stream } & \multicolumn{2}{|c|}{ Measure } & \multicolumn{3}{|c|}{$\begin{array}{l}\text { Parameter estimated } \\
\text { of GEV (Moment method) }\end{array}$} & \multicolumn{2}{|c|}{ Dam variability $(*)$} & \multicolumn{2}{|c|}{$\begin{array}{l}\text { Goodness } \\
\text { of fit (K-S) }\end{array}$} \\
\hline & \multirow[b]{2}{*}{ \# } & \multirow[b]{2}{*}{ Description } & \multirow[b]{2}{*}{ K } & \multirow[b]{2}{*}{$\begin{array}{l}\beta \\
\left(\mathrm{m}^{3} \mathrm{~s}^{-1}\right)\end{array}$} & \multirow[b]{2}{*}{$\begin{array}{l}\mu \\
\left(\mathrm{m}^{3} \mathrm{~s}^{-1}\right)\end{array}$} & \multirow{2}{*}{$\begin{array}{l}\text { Different } \\
\text { storage - } \\
\text { capacity } \\
\text { DEVST \% }\end{array}$} & \multirow{2}{*}{$\begin{array}{l}\text { Bottom } \\
\text { outlet/no } \\
\text { outlet } \\
\text { DEVST \% }\end{array}$} & \multirow[b]{2}{*}{$\mathrm{D}$} & \multirow[b]{2}{*}{ p-value } \\
\hline & & & & & & & & & \\
\hline \multirow{16}{*}{$\begin{array}{l}\text { Alberche } \\
\text { River }\end{array}$} & - & Non & 0.269 & 730.121 & 1054.278 & - & - & 0.143 & 0.999 \\
\hline & $1-4$ & $\begin{array}{l}\text { Obispo dam } \\
\qquad(\mathrm{h}=70-40 \mathrm{~m})\end{array}$ & 0.277 & 719.160 & 1048.989 & 0 & 6.8 & 0.145 & 0.999 \\
\hline & 5 & $\begin{array}{l}\text { Navarrevisca dam } \\
\quad(h=50 \mathrm{~m})\end{array}$ & 0.274 & 620.805 & 984.033 & 4.3 & 3.5 & 0.164 & 0.993 \\
\hline & 6 & $\begin{array}{l}\text { Navarrevisca dam } \\
\quad(h=40 \mathrm{~m})\end{array}$ & 0.270 & 619.907 & 933.123 & 6.7 & 1.7 & 0.145 & 0.999 \\
\hline & 7 & $\begin{array}{l}\text { Navarrevisca dam } \\
\quad(h=30 \mathrm{~m})\end{array}$ & 0.255 & 673.250 & 961.917 & 3.6 & 0.7 & 0.152 & 0.998 \\
\hline & 8 & $\begin{array}{l}\text { Navarrevisca dam } \\
\quad(h=20 \mathrm{~m})\end{array}$ & 0.271 & 720.140 & 1035.501 & 0.5 & 0.4 & 0.143 & 0.998 \\
\hline & 9 & $\begin{array}{l}\text { Morisco dam } \\
\quad(h=60 \mathrm{~m})\end{array}$ & 0.289 & 544.221 & 734.911 & 2.0 & 6.7 & 0.152 & 0.999 \\
\hline & 10 & $\begin{array}{l}\text { Morisco dam } \\
\quad(h=50 \mathrm{~m})\end{array}$ & 0.272 & 561.702 & 737.583 & 3.5 & 6.2 & 0.156 & 0.998 \\
\hline & 11 & $\begin{array}{l}\text { Morisco dam } \\
(h=40 \mathrm{~m})\end{array}$ & 0.281 & 581.343 & 776.953 & 7.3 & 5.3 & 0.158 & 0.998 \\
\hline & 12 & $\begin{array}{l}\text { Morisco dam } \\
\quad(h=30 \mathrm{~m})\end{array}$ & 0.240 & 620.030 & 820.357 & 7.1 & 4.3 & 0.139 & 0.998 \\
\hline & 13 & Comb. $4+5+9$ & 0.244 & 287.614 & 308.548 & 7.4 & 9.3 & 0.136 & 0.997 \\
\hline & 14 & $\operatorname{FHCD}(h=12 \mathrm{~m})$ & 0.245 & 419.577 & 471.645 & - & 0 & 0.135 & 0.999 \\
\hline & 15 & $\operatorname{FHCD}(h=6 \mathrm{~m})$ & 0.235 & 420.077 & 467.330 & - & 0 & 0.138 & 0.999 \\
\hline & 16 & Combination $13+4$ & 0.245 & 414.155 & 464.038 & 0.1 & 6.8 & 0.138 & 0.999 \\
\hline & 17 & Combination $13+5$ & 0.229 & 316.5 & 367.327 & 7.1 & 3.5 & 0.144 & 0.998 \\
\hline & 18 & Combination $13+9$ & 0.254 & 249.355 & 250.263 & 1.7 & 6.7 & 0.148 & 0.998 \\
\hline \multirow{2}{*}{$\begin{array}{c}\text { Chorrerón } \\
\text { Stream }\end{array}$} & - & Non & 0.112 & 62.952 & 71.374 & - & - & 0.170 & 0.994 \\
\hline & 19 & Storm tank & 0.093 & 59.331 & 27.804 & - & - & 0.206 & 0.967 \\
\hline
\end{tabular}


statistical parameters obtained for each alternative considered, as well as mean quantified deviation due to initial storage and the operativity of bottom outlets.

Finally, past flood evidence was taken into account through the analysis of tree-rings, which provided information on unrecorded past flood events. Then, we compared the expected value of the statistical fit using GEV distribution (considering a 500-year time horizon, Fig. 4) of: the flood frequency obtained with 1) the extended flow gauge with treering data, and 2) the hydrologic model (i.e. current regime). The results showed a coefficient of variation of $40.9 \%$.

\subsection{Hydraulic Analysis}

This part of the analysis is concerned with the evaluation of the water depth for all scenarios considered: (i.e. S1 and S2). The hydraulic parameterization and boundary conditions are shown in Fig. 5. Floodplain and channel topography data were obtained during field work for this analysis. The river cross sections were taken in the island river area for 1D implementation, and bathymetry (scale 1:500) generated for the built-up area. Urban topography using $\mathrm{CAD}$, (scale 1:1000) was also completed including contour lines, buildings and the most important infrastructure in terms of hydraulic modeling (i.e., bridges, streets) was used to generate a triangulated irregular network (TIN). Finally an ASCII regular mesh $(2 \times$ $2 \mathrm{~m}$ ) of the study site was derived from the TIN which was incorporated into MIKE 21, while initial cross sections were incorporated into MIKE 11.

The roughness coefficient (Manning's $n$ value) was obtained for both the channel and floodplain from delineation of homogeneous units by roughness. This information was placed discretely in cross sections, with continuous integration of the twodimensional model. The initial roughness values used in the iterative calibration procedure were based on the delineation of homogeneous land-use according to the criteria defined by Chow (1959).

Turbulent flow characteristics were incorporated using the eddy viscosity parameter; however, as this data is unknown and could not be measured during flooding, an approximate value of $0.0045 \mathrm{~m}^{2} \mathrm{~s}^{-1}$ for the river was used, as suggested in the literature (Yong 2005). The geometry of structures including bridges and weirs was also incorporated into the model. Finally, boundary conditions were given upstream assuming normal depth since the
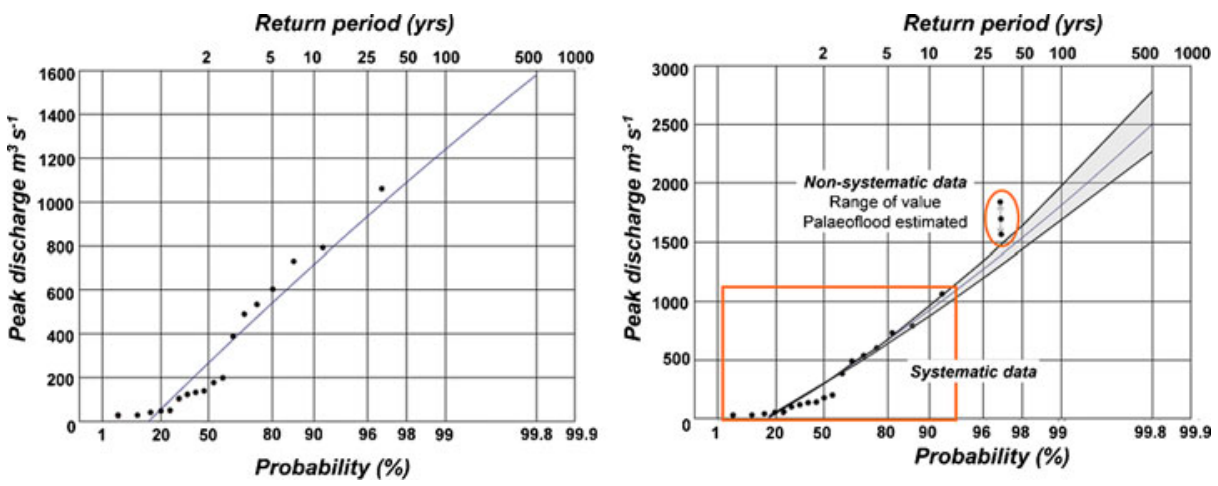

Fig. 4 Results of peak discharge percentiles obtained from the flow gauge station at Navaluenga derived from the systematic record (left) and the extended series with non-systematic data (1970 paleoflood event estimated with tree-ring analysis, $1684.3 \pm 519.2 \mathrm{~m}^{3} \mathrm{~s}^{-1}$; right). Statistical analysis tested by goodness of fit ( $\mathrm{p}$-value $>0.05$ ) 

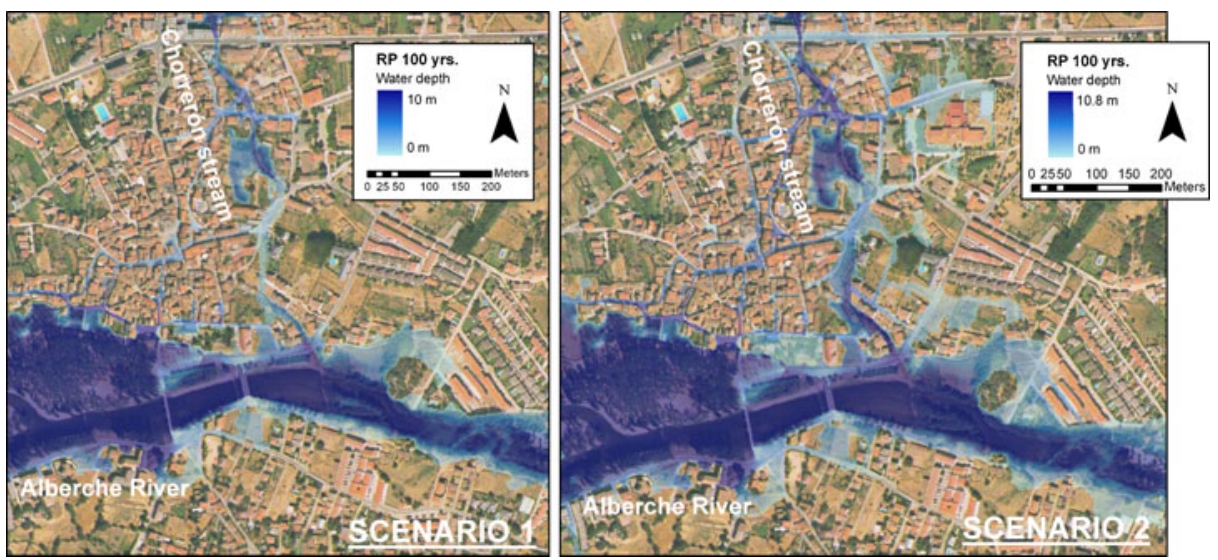

Fig. 5 Example of flood area at the study site obtained by hydraulic modeling for expected 100-year flood event in scenarios S1 and S2

channel is more or less longitudinally uniform in this reach. The hydraulic simulation was carried out with a time range of $25,000 \mathrm{~s}$ with a time step interval of $0.05 \mathrm{~s}$, which ensured stable conditions in the simulation.

The hydraulic calibration focused on defining the range of possible roughness values as defined in Chow (1959). To do this, the gauge station rating curve and scars on trees, previously dated by dendrogeomorphological techniques (Ballesteros et al. 2011b), were used. The incorporation of tree scars provided multiple point controls which improve the spatially-distributed roughness calibration. Six dendrogeomorphologically well-defined recorded flood events were chosen to apply an iterative method varying the roughness parameters to allocate values minimizing the error between the observed water height (point controls, tree scars and rating curve) and simulated values. An iterative calibration routine was used to adjust model parameters until an acceptable match between simulated peak flow and observed peak flow was reached. The quantitative measure of this match was described by the objective function percentage error in peak discharge (Huberlandt et al. 2008). The optimal parameters that minimize the above objective function were found using an iterative search process based on the univariate gradient method. The observed variability derived in this process has been considered as parametric uncertainty (Neuhold et al. 2009; Table 4).

\subsection{Damage Loss Estimation}

The focus here was on tangible costs related to structural damage to buildings and properties based on the depth-damage function for flood damage estimation.

The analysis is based on two catalogs of residential depth-damage functions:

1. the USACE (1992) catalog, a review of different damage functions derived from deterministic estimation for different flood event typologies;

2. the PATRICOVA (2002) catalog, which includes different damage functions based on idealized element replacement values for the Mediterranean area.

The deterministic depth-damage functions considered here were derived from stream flooding caused by precipitation from intense thunderstorm activity and long 
Table 4 Variability obtained from the roughness calibration procedure comparing flow gauge data at specific points and spatially-distributed scar height measurements on trees

\begin{tabular}{|c|c|c|c|c|c|c|c|}
\hline \multirow[t]{2}{*}{$\begin{array}{l}\text { Flood } \\
\text { event (yr) }\end{array}$} & \multirow[t]{2}{*}{$\begin{array}{l}\text { Peak discharge } \\
\text { of event }\left(\mathrm{m}^{3} / \mathrm{s}\right)\end{array}$} & \multirow[t]{2}{*}{$\begin{array}{l}\text { Rating curve } \\
\text { measured }(\mathrm{cm})\end{array}$} & \multicolumn{2}{|c|}{$\begin{array}{l}\text { Manning's values } \\
\left(^{*} \text {, percentage of the }\right. \\
\text { defined range according } \\
\text { with Chow 1959) }\end{array}$} & \multicolumn{2}{|c|}{$\begin{array}{l}\text { Difference } \\
\text { between } \\
\text { calibrations* }\end{array}$} & \multirow[t]{2}{*}{$\begin{array}{l}\text { Variability in the } \\
\text { water depth }(\%)\end{array}$} \\
\hline & & & $\begin{array}{l}\text { Defined with } \\
\text { scar on trees }\end{array}$ & $\begin{array}{l}\text { Defined with } \\
\text { flow gauge }\end{array}$ & $(\%)$ & $\mathrm{cm}$ & \\
\hline 2005 & 196.4 & 175 & 20 & -90 & 110 & 24.2 & 13.8 \\
\hline 2003 & 177.5 & 156 & -90 & -70 & 20 & 4.4 & 2.8 \\
\hline 2002 & 478.5 & 203 & -140 & -80 & 60 & 13.2 & 6.5 \\
\hline 2000 & 532.7 & 203 & 0 & -60 & 60 & 13.2 & 6.5 \\
\hline 1996 & 730.4 & 208 & 30 & -60 & 90 & 19.8 & 9.5 \\
\hline 1993 & 792.8 & 198 & -70 & -80 & 10 & 2.2 & 1.1 \\
\hline \multicolumn{3}{|l|}{ Average } & -41.6 & -73.3 & 58.3 & 12.8 & 6.7 \\
\hline \multicolumn{3}{|l|}{ Std. } & 68.5 & 12.1 & 38.6 & 8.5 & 4.5 \\
\hline \multicolumn{3}{|c|}{ Percentile 99} & 30 & -60 & 110 & 24.2 & 13.8 \\
\hline \multicolumn{3}{|c|}{ Percentile 5} & -140 & -90 & 10 & 2.2 & 1.1 \\
\hline \multicolumn{3}{|c|}{ Stnd. Skewness } & -0.383 & -0.075 & 0.002 & 0.002 & 0.452 \\
\hline \multicolumn{3}{|c|}{ Stnd. Kurtosis } & -0.848 & -0.774 & -0.664 & -0.664 & -0.080 \\
\hline
\end{tabular}

duration frontal activity. The typology of residential uses taken into account was (Fig. 6):

1. single storey with basement;

2. single storey without basement;

3. multi-storey with basement;

4. multi-storey without basement;

5. mobile home;

6. electricity facility;

7. public areas.
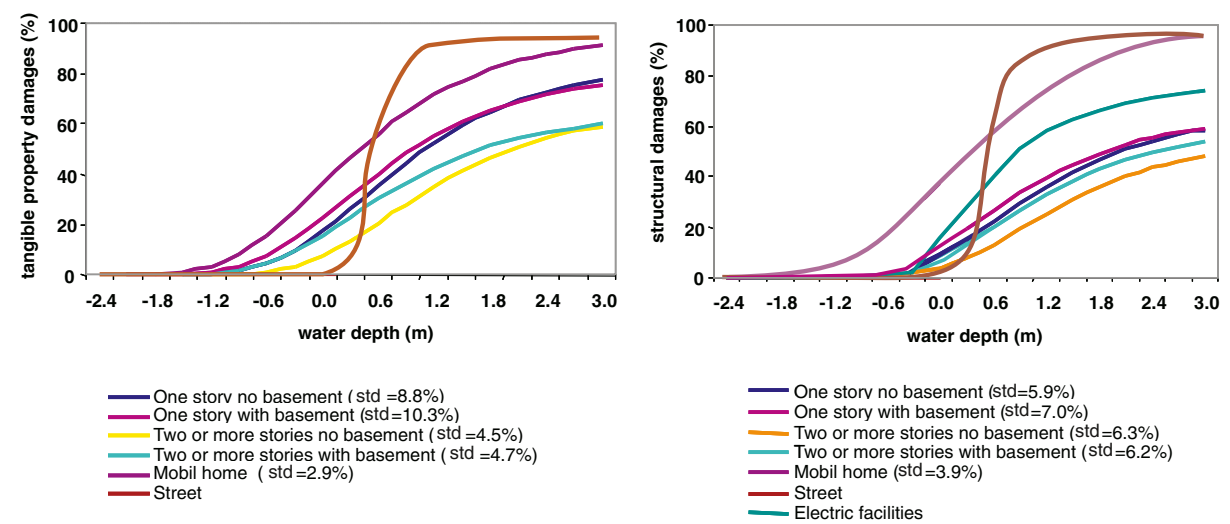

Fig. 6 Representation of depth-damage function by type of building used in this study 
To evaluate the impact of the flooding several GIS tools based on statistical and spatial analysis was used following the guidelines proposed by Kang et al. (2005). Residential use classification was based on the local cadastral map. The percentage change in value as a result of flood damage is based on the average market price for residential buildings (i.e. $€ 150,000$ ), and on the replacement value for electrical facilities (i.e. $€ 80,000$ ) and public areas (i.e. $€ 60 / \mathrm{m}^{2}$; PATRICOVA 2002). For residential facilities, the structural damage was taken as $15 \%$ of the average building price; the cost of damage to contents was assumed to be $20 \%$ of the total value. The loss-return period functions for two possible risk scenarios are considered here (S1 and S2) (Fig. 7). In the current situation (natural flow regime) the estimated expected loss for an exceedance probability of $P_{f}=0.002$ is approximately $€ 1.6$ million for scenario $\mathrm{S} 1$, and $€ 3.1$ million for scenario $\mathrm{S} 2$.

\subsection{Flood Risk Cost-Based Decision Analysis}

The flood risk should be computed in terms of the total annual expected cost, i.e.,

$$
E\left(C_{T}\right)=\sum_{i=1}^{n} E\left(C_{T}\right)_{i}=\sum_{i=1}^{n} E\left[C_{0, i}+D_{i}(x, \Phi)\right]
$$

where $n$ is the number of possible interventions considered; $\mathrm{E}\left[C_{T}\right]_{i}$ is the expected total cost derived from the intervention measures $i$ and possible associated damage; $C_{0, i}$ is the cost of implementing measure $i$; and $D_{i}(x, \Phi)$ is the total cost of damage in the area when subjected to an event $x$. Note that $D$ depends on $\Phi$, which is a vector parameter describing the physical characteristics of the affected area (water depth, typology, etc.). Because decisions need to be made at time $t=0$, all costs need to be discounted. Discounting to $t=0$ can be made using a continuous discounting function, e.g., $\exp (-\gamma t)$, where $\gamma$ is the discount rate ( $\gamma$ approx 3-7 \%). This can be done using a capital recovery factor (CFR), expressed as:

$$
C F R=\frac{i(1+1)^{t}}{(1+i)^{t}-1}
$$

which depends on the time horizon $(t=500$ years) and an average interest rate $i$, which usually varies between $3 \%$ and $7 \%$, based on 20 years of historical data (Banco de España, 2011).

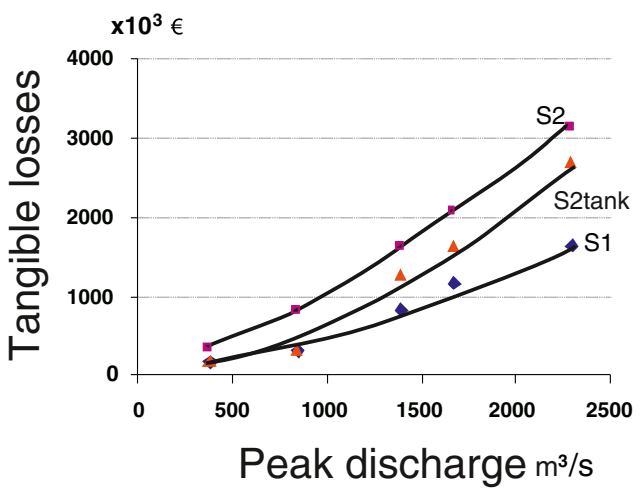

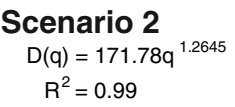

\section{Scenario 2, storm tank}

$D(q)=6.2202 x^{1.6706}$

$R^{2}=0.95$

\section{Scenario 1}

$D(q)=40.337 x^{1.3686}$ $R^{2}=0.97$

Fig. 7 Expected flood-loss function for Navaluenga with peak discharge for both hazard scenarios considered 
In Eq. 1, the term $C_{0 i}$ depends exclusively on the cost of the alternative (i.e. flood defense structure) and includes factors such as typology, configuration and size at preliminary project level. In the case of dams, these are considered as multipurpose (e.g., tourism, water supply) and thus only $20 \%$ of the total cost has been attributed to flood defense.

The second term in Eq. 2, $D_{i}(x, \Phi)$, depends on the magnitude of the flood event and the vulnerability of Navaluenga. Estimating this term is the real problem in a flood risk analysis (Merz et al. 2010). Then the total annual expected damage associated with intervention measure $x$ is calculated as Equation 4 (Cheng et al. 1993):

$$
E\left[D_{i}(x)\right]=\sum_{j=1}^{2} \sum_{i=1}^{n=500} \frac{1}{T_{i}} \int_{0}^{\infty} D(\Phi, x)_{j} f_{\Phi}(x, \Phi) \mathrm{d} \Phi
$$

where $D_{i}(x, \Phi)$ is the estimated flood damage (section 3.3.3), which depends on the vector parameter $\Phi$ (section 3.3.2), defined mainly by water depth and peak discharge function for return period $T_{i}$ (section 3.3.1). Note also that the analysis is carried out for two hazard scenarios defined by the sub-index $j$ (section 3.3.2). The damage loss uncertainties are represented by the density function $f_{\Phi}(x, \Phi)$ which was assumed to be log-normal (Fig. 9). A summary of coefficient of variation values (COV) for different aspects of the analysis can be observed in Table 5 .

\section{Results and Discussion}

To make a comparative analysis of the alternatives considered, the results were divided into three groups:

i) Group 1: Expected annual cost lower than $€ 3.1$ million for $\mathrm{S} 1$ and $€ 2.8$ million for $\mathrm{S} 2$. These alternatives show the lowest expected losses. Depending on the construction cost, these alternatives may be feasible.

ii) Group 2: Expected annual cost between $€ 3.1$ and $€ 6.8$ million for $\mathrm{S} 1$ and between $€ 2.8$ and $€ 7.4$ million for S2. Alternatives within this zone are not optimal but may be feasible where specific considerations go beyond the scope of only the flooding problem.

iii) Group 3: Expected annual costs higher than $€ 6.8$ million for $\mathrm{S} 1$ and $€ 7.4$ million for S2. Alternatives within this zone are unreasonable due to their high costs.

Figures 8 and 9 show the annual expected flood losses and annual expected cost of flood defense incurred for the two hazard scenarios considered. For S1, 18 different alternatives

Table 5 Summary of variability quantified during the risk analysis process

\begin{tabular}{llc}
\hline Analysis step & Derived from & $\begin{array}{l}\text { Deviation } \\
\text { quantified (\%) }\end{array}$ \\
\hline Flood frequency & Extending flow data & 40.9 \\
& Calibration procedure & 23.3 \\
& Different storage -capacity & 4.2 \\
& Bottom outlet/no outlet & 4.7 \\
Hydraulic model & Calibration procedure & 6.7 \\
Damage estimation & Tangibles property damages & 6.2 \\
& Structural damages & 5.8 \\
\hline
\end{tabular}




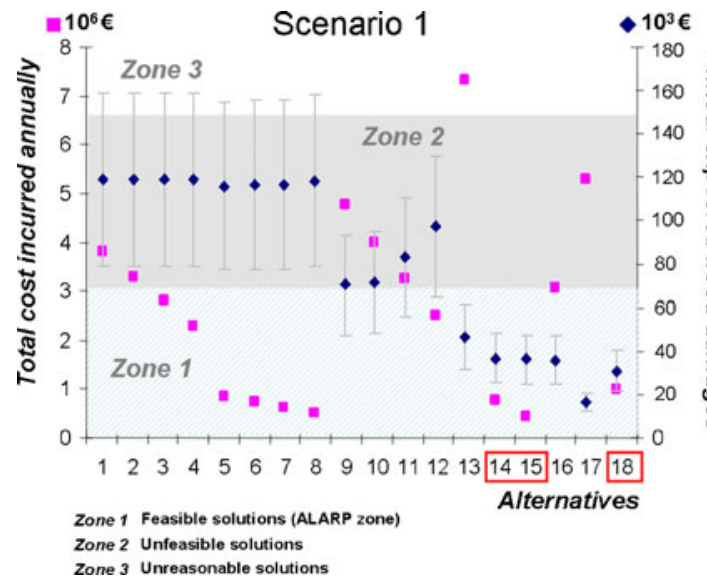

\section{Alternatives}

1 Venta obispo dam $(h=70)$ 2 Venta obispo dam $(h=60)$ 3 Venta obispo dam $(\mathrm{h}=50)$ 4 Venta obispo dam $(h=40)$

5 Navarrevisca dam $(h=50)$

6 Navarrevisca dam $(h=40)$

7 Navarrevisca dam $(h=30)$

8 Navarrevisca dam $(h=20)$

9 Morisco dam $(h=60)$

10 Morisco dam $(h=50)$

11 Morisco dam $(h=40)$

12 Morisco dam $(h=30)$

13 Comb. Alternatives $(4+5+9)$

14 Dikes of HFC ( $h=12)$

15 Dikes of HFC $(h=6)$

16 Comb. Alternatives (14+4)

17 Comb. Alternatives (14+9)

18 Comb. Alternatives $(14+5)$

Feasible solutions (ALARP zone)

Zone 3 Unreasonable solutions

Fig. 8 Comparison of the reduction in expected loss values for the different alternatives and the annual total cost incurred for their implementation in Scenario 1

were evaluated; these include several individual structural measures and their combinations. For Scenario S2, 24 alternatives were considered. For both scenarios, there are almost 6 cases in which the annual flood risk is completely within reasonable limits (Zone 1); although for S2 there are 4 more alternatives which present around $50 \%$ probability of annual flood losses within zone 1 (Table 6).

Based on these results, the optimal alternatives to decrease the flood risk in Navaluenga to a reasonable level in S1 were: to build smaller dams (S-Dams) 12 or $6 \mathrm{~m}$ high (Fig. 3 shows $\mathrm{S}$-Dam locations) and combine these with the projected Navarrevisca dam (optimal height of dam $50 \mathrm{~m}$ ). However, for scenario S2, the best alternative is to build S-Dams (both 12 and $6 \mathrm{~m}$ high) and a storm tank in the Chorrerón stream.

In the cases where S-Dams are built in combination with Navarrevisca and Venta del Obispo Dams there is $\geq 50 \%$ probability that the associated annual expected flood losses would be in group 1 (Table 4, alternative S2: 14, 15, 16 and 18). Although these alternatives may also appear interesting, they only affect the Alberche River, making them less

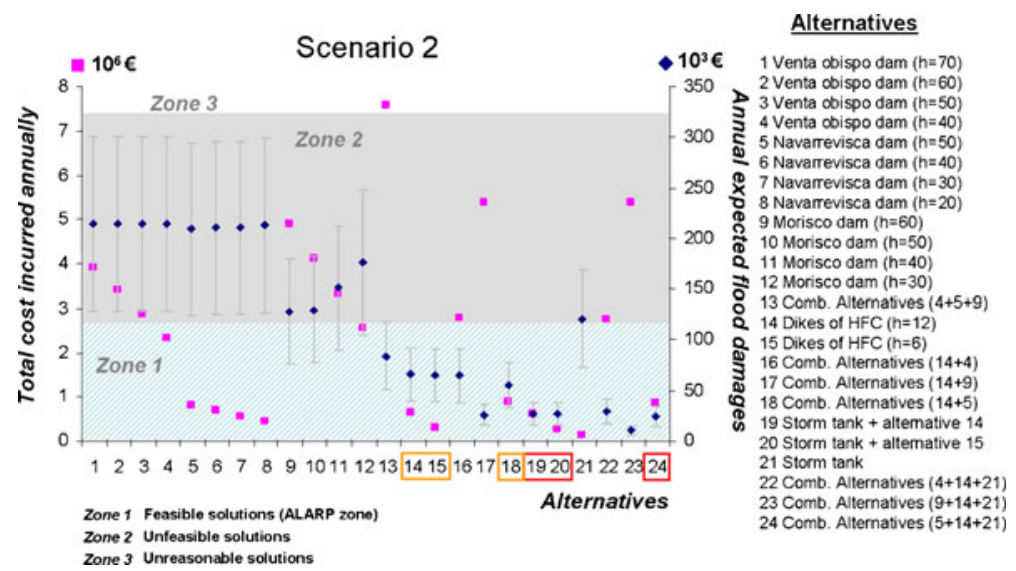

Fig. 9 Comparison of the reduction in expected loss values for the different alternatives and the annual total cost incurred for their implementation in Scenario 2 
Table 6 Probability that the annual expected value of losses obtained will be within the acceptability zone (Zone 1)

\begin{tabular}{|c|c|c|c|c|c|c|c|c|c|}
\hline Alternative & Scenario & Zone 1 & Zone 2 & Zone 3 & Alternative & Scenario & Zone 1 & Zone 2 & Zone 3 \\
\hline \multirow[t]{2}{*}{1} & S1 & 0 & 0.47 & 0.52 & 13 & S1 & 0.92 & 0.08 & 0 \\
\hline & S2 & 0 & 0.31 & 0.69 & & S2 & 0.21 & 0.79 & 0 \\
\hline \multirow[t]{2}{*}{2} & S1 & 0 & 0.47 & 0.52 & 14 & S1 & 1 & 0 & 0 \\
\hline & S2 & 0 & 0.31 & 0.69 & & S2 & 0.48 & 0.52 & 0 \\
\hline \multirow[t]{2}{*}{3} & S1 & 0 & 0.47 & 0.52 & 15 & S1 & 1 & 0 & 0 \\
\hline & S2 & 0 & 0.31 & 0.69 & & S2 & 0.49 & 0.51 & 0 \\
\hline \multirow[t]{2}{*}{4} & S1 & 0 & 0.47 & 0.52 & 16 & S1 & 1 & 0 & 0 \\
\hline & S2 & 0 & 0.31 & 0.69 & & S2 & 0.51 & 0.49 & 0 \\
\hline \multirow[t]{2}{*}{5} & S1 & 0 & 0.51 & 0.49 & 17 & S1 & 1 & 0 & 0 \\
\hline & S2 & 0 & 0.34 & 0.66 & & S2 & 1 & 0 & 0 \\
\hline \multirow[t]{2}{*}{6} & S1 & 0 & 0.49 & 0.51 & 18 & S1 & 1 & 0 & 0 \\
\hline & S2 & 0 & 0.33 & 0.67 & & S2 & 0.72 & 0.28 & 0 \\
\hline \multirow[t]{2}{*}{7} & S1 & 0 & 0.51 & 0.49 & 19 & S1 & - & - & - \\
\hline & S2 & 0 & 0.33 & 0.67 & & S2 & 1 & 0 & 0 \\
\hline \multirow[t]{2}{*}{8} & S1 & 0 & 0.47 & 0.53 & 20 & S1 & - & - & - \\
\hline & S2 & 0 & 0.31 & 0.69 & & S2 & 1 & 0 & 0 \\
\hline \multirow[t]{2}{*}{9} & S1 & 0.33 & 0.66 & 0 & 21 & S1 & - & - & - \\
\hline & S2 & 0 & 1 & 0 & & S2 & 0 & 1 & 0 \\
\hline \multirow[t]{2}{*}{10} & S1 & 0.32 & 0.68 & 0 & 22 & S1 & - & - & - \\
\hline & S2 & 0 & 1 & 0 & & S2 & 1 & 0 & 0 \\
\hline \multirow[t]{2}{*}{11} & S1 & 0.16 & 0.83 & 0.01 & 23 & S1 & - & - & - \\
\hline & S2 & 0 & 0.75 & 0.25 & & S2 & 1 & 0 & 0 \\
\hline \multirow[t]{2}{*}{12} & S1 & 0.01 & 0.74 & 0.25 & 24 & S1 & - & - & - \\
\hline & $\mathrm{S} 2$ & 0 & 0.54 & 0.46 & & S2 & 1 & 0 & 0 \\
\hline
\end{tabular}

advisable. This is because the definition of S2, which implies that the tributary stream running through the village also floods, has shown greater potential for expected direct losses as well as a greater threat to the population, compared with S1. In fact, for S2 the average annual expected loss for the optimal alternative is $€ 25,644$ (standard deviation: $€ 10,257)$, implying a reduction in flood risk of almost $87 \%$ compared with the current situation where annual expected losses rise to $€ 210,660$ (standard deviation: $€ 86,431$ ). However, optimum alternatives in S1 provided slightly higher annual expected losses (€26,309, standard deviation: $€ 10,962)$, i.e. a $73 \%$ reduction in flood risk compared with the current expected annual losses (€99,266, standard deviation: €41,359).

In both scenarios, the average construction costs of the optimum alternatives would be $€ 542,475$ (S1) and $€ 550,073$ (S2). These results definitively support the idea that the best alternatives for flood mitigation in Navaluenga are those chosen for S2 (i.e. building a combination of S-Dams in tributary streams and a storm tank in the Chorreron stream). In fact, the cheaper and easier alternative of building a storm tank outside the village on the Chorrerón stream has been shown to be fundamental. To build only large dams (i.e. Venta del Obispo or Morisco Dams) could give the population a false sense of security, but could result in increased exposure and vulnerability and thus greater expected flood risk. In Mediterranean cultures, people who live downstream of a dam think that the reservoir will 
laminate all the flood risk. This often leads to the colonization of hazardous areas of the floodplain previously dominated by river dynamics during floods. This increases exposure and vulnerability (Rodrigues et al. 2002), as shown previously by Diez (2001) in the same region. Dam failure may also occur provoking catastrophic events as seen in Spain during the last century (Consuegra (Toledo) 1891, Tous (Valencia) 1982, Ribadelago de Tera (Zamora) 1957, Biescas (Huesca, smaller dams) 1996; Diez-Herrero et al. 2009)

Despite the theoretically high capacity of large dams to reduce runoff (Heidari 2009), the reason why they do not appear as reasonable alternatives here are: i) the high construction cost, although the multi-purpose nature of the dams has been considered and is reflected in the inclusion of only $15 \%$ of the total cost in the estimated installation cost; and ii) the location of the dams within the hydrological system. The estimated construction cost of the dams is considered here to be reasonable and therefore its uncertainties do not affect the decision-making. This estimate was made based on the relationship between the technical characteristics (i.e. typology and concrete volume) and the updated bidding cost of 13 recent large dams, built in Spain during the last 15 years (MMA 2008); the cost attributable to flood protection was however fixed arbitrarily. Lower percentages could be also taken into account; but the high cost of such structures continues to make them an unreasonable alternative. Nevertheless, the most important factor explaining the non-effectiveness of dams is the pre-defined location of the dam at the previous project level. This present study shows that the criteria used for a large dam site (i.e. maximum overall economic efficiency, river constriction and bedrock, high water storage capacity and high hydraulic jump for electricity production), do not always match the criteria required for proper flood defenses. The spatial location of the structural measures within the hydro system seems to be the key to efficient flood defense. Thus, structures planned on tributary streams closest to Navaluenga will generally be more effective than large structures located further away.

The uncertainty around expected flood losses is controlled by the accuracy in evaluating past flood evidence; this uncertainty results in an average coefficient of variation of $41.2 \%$. Several studies indicate that the source of most uncertainties in flood risk assessment is the incomplete understanding of the flood-frequency law (Merz et al. 2010; Apel et al. 2004). In agreement with this, here the main source of uncertainty (almost $40.6 \%$ ) was assigned to the variability observed in flood-frequency after including flood evidence from tree-rings. The sources of uncertainties such as roughness parameters were also assessed in this study, but their contribution to the global uncertainty was marginal.

Other sources of uncertainty are not considered here, e.g. changes in land use, adaptive capacity (Merz et al. 2010) of a specific population group or the impact of climate change, which should be taken into account when assessing flood risk in today's changing world (Plate 2002). There is an uncertainty in the peak discharge estimation associated with the spatial-temporal rainfall disaggregation applied in this study. Although this uncertainty is not negligible for hydraulic work design purposes, the lack of enough detailed data limited the use of more complex distributed hydrological models. Nevertheless, we do not expect that the rainfall disaggregation used here alter significantly the final flood risk estimation.

Finally, because information to calibrate sediment transport in the study river was not available, we could not include uncertainties from river morphological changes, which in previous studies seem to be much higher than the influence of discharge input variations (Neuhold et al. 2009). To address these questions, future work on this river basin should focus on the search for more evidence and its relationship with climatic conditions to allow realistic local scenarios to be defined.

In this study economic criteria were used to determine the acceptability level. Other authors have also used the number of expected fatalities for this purpose (Jonkman 2007). In general, all 
criteria used are aimed at reducing the expected risk as far as reasonably possible (ALARP, HSE 2001; Ayala-Carcedo 2001). Further studies in this field should be focused on a multi-criteria decision process, where several factors are taken into consideration to select the best option.

\section{Conclusions}

This paper presents a flood risk assessment for the town of Navaluenga in Spain. The objective of the study is to compare the possible alternatives and decide on the best intervention measures. The comparison of the alternatives is cost-based. This analysis shows that uncertainties derived from non-systematic data (i.e. tree-ring analysis) included in the flood frequency definition can be used in flood risk assessment.

Results have shown clearly that the best flood defense strategy for Navaluenga is to build a combination of S-Dams on the tributary stream and a storm tank on the Chorreron stream. The importance of spatial location within the hydrologic system has also been demonstrated as well as the possible incompatibility of criteria used to define the locations of dams intended for a water reservoir or electricity generation with those for dams intended as flood protection for a given location. Although more research is needed to define uncertainties due to global change and the constantly changing environmental conditions, in agreement with Benito et al. 2005, the authors want to emphasize the usefulness of including non-systematic data in pragmatic decision-making procedures.

Acknowledgments This work has been funded by the MAS Dendro-Avenidas project (CGL2010-19274), MAPFRE foundation and the Geological Survey of Spain (IGME). The authors would like to thank the local authorities of Navaluenga for their collaboration, as well as the anonymous reviewer, who have improved significantly this paper.

\section{References}

Apel H, Thieken AH, Merz B, Blöschl G (2004) Flood risk assessment and associated uncertainty. Nat Hazards Earth Syst Sci 4:295-308

Ayala-Carcedo FJ (2001) Natural disasters mitigation in the world and sustainable development: a risk analysis approach. Bol Geo Min 112(4):43-64

Baker VR (2008) Paleoflood hydrology: origin, progress, prospects. Geomorphology 101:1-13

Ballesteros Cánovas JA, Eguíbar M, Bodoque JM, Díez-Herrero A, Stoffel M, Gutiérrez-Pérez I (2011a) Estimating flash flood discharge in an ungaguged mountan catchment with 2D hydraulic models and dendrogeomorphic paleostage indicators. Hydrol Process 25(6):970-979

Ballesteros Cánovas JA, Bodoque JM, Díez-Herrero A, Sánchez-Silva M, Stoffel M (2011b) Calibration of floodplain roughness and estimation of flood discharge based on tree-ring evidence and hydraulic modeling. J Hydro 403(1-2):103-115

Banco de España (2011) Banco de España Eurosistema. http://www.bde.es/webbde/es/estadis/infoest/tipos/ tipos.html. Accessed 1 June 2011

Benito G (2006) Riesgos de inundaciones: tendencias históricas y perspectivas de acuerdo con el cambio climático. Rev Cuater Geo 20(3-4):29-44

Benito G, Thorndycraft VR (2004) Systematic, palaeoflood and historical data for the improvement of flood risk estimation, methodological guidelines. CSIC, Madrid

Benito G, Ouarda TBMJ, Bárdossy A (2005) Applications of palaeoflood hydrology and historical data in flood risk analysis. J Hydro 313(1-2):1-2

CEA (2007) Reducing the social and economic impact of climate change and natural catastrophes-inurance solutions and public-private partnerships. CEA, Brussels

Chang M, Lee R (1974) Objective double mass analysis. Water Resour Res 10(6):1123-1126 
Cheng ST, Yen BC, Tang WH (1993) Stochastic risk modeling of dam overtopping. In: Yen BC, Tung YK (eds) Reliability and uncertainty analyses in hydraulic design. ASCE, Reston, pp 123-132

Chow VT (1959) Open-channel Hydraulics. McGraw-Hill, New York

Chow VT, Maidment DR, Mays LW (1988) Applied hydrology. McGraw-Hill, New York

CHT (1992) Plan Hidrológico. Proyecto de Directrices. Condederación Hidrográfica del Tajo, Madrid

CHT (2012) Confederación Hidrográfica del Tajo. http://www.chtajo.es/Informacion\%20Ciudadano/ Descargas/Paginas/default.aspx. Accessed 5 September 2012

DHI (2008) MIKE 21 flow model. Hydrodinamic module. Scientific Documentation. DHI

Dietrich J, Schumann AH, Redetzky M, Walther J, Denhard M, Wang Y, Pfützner B, Büttner U (2009) Assessing uncertainties in flood forecasts for decision making: prototype of an operational flood management system integrating ensemble predictions. Nat Hazards Earth Syst Sci 9:1529-1540

Díez A (2001) Geomorfología e Hidrología fluvial del río Alberche. Modelos y SIG para la gestión de riberas. Dissertation. Universidad Complutense de Madrid.

Díez-Herrero A, Laín-Huerta L, Llorente-Isidro MA (2009) Handbook on flood hazard mapping methodologies. Spain Geological Survey, Madrid

Dutta D, Herath S, Musiake K (2006) An application of a flood risk analysis system for impact analysis of a flood control plan in a river basin. Hydrol Process 20:1365-1384

Eum HI, Vasan A, Simonovic SP (2012) Integrated reservoir management system for flood risk assessment under climate change. Water Resour Manage 26(13):3785-3802

Faber R (2006) Flood risk analysis: Residual risks and uncertainties in an Austrian context. Dissertation. University of Natural Resources and Applied Life Sciences

Ferrer M, González Vallejo L, García López-Davalillo JC, Rodíguez Franco JA (2004) Pérdidas por Terremotos e inundaciones en España durante el periodo 1987-2001 y su estimación para los próximos 30 años (2004-2033). Consorcio Compensación de Seguros, Madrid

Gaume E, Bain V, Bernardara P et al (2009) A compilation of data on European flash floods. J Hydro 367(1-2):70-78

GTAGU (2010) Precio Centro 2010 Aparejadores Guadalajara, S.L.U. http://www.coaatgu.com/gtagu/. Accessed 12 May 2010

Heidari A (2009) Structural master plan of flood mitigation measures. Nat Hazards Earth Syst Sci 9:61-75

HSE (2001) Reducing risks, protecting people. HSE's decision-making process. Health and Safety Executive, Suffolk

Huberlandt U, von Eschenbach ADE, Buchwald I (2008) A space-time hybrid hourly rainfall model for derived flood frequency analysis. Hydrol Earth Syst Sci 12(6):1353-1367

IPCC, Climate Change (2001) Impacts, adaptation and vulnerability. In: McCarthy JJ, Canziani OF, Leary NA, Dokken DJ, White KS (eds) Contribution of working group II to the third assessment report of IPCC. Cambridge University Press, Cambridge

Jonkman SN (2007) Loss of life estimation in flood risk assessment. Theory and applications. Dissertation. Technische Universiteit Delft

Kang J-L, Su M-D, Chang L-F (2005) Loss functions and framework for regional flood damage estimation in residential area. J Mar Sci Technol 13(3):193-199

Kohler MA (1949) Double-mass analysis for testing the consistency of records and for making required adjustments. B Am Meteorol Soc 30:188-189

Loucks DP, Stedinger JR, DaArryl WD, Stakhiv EZ (2008) Private and public responses to flood risks. Int J Water Resour D24(4):541-553

Merz B, Thieken A, Blöschl G (2002) Uncertainty analysis for flood risk estimation, Intern. Commission for the Hydrology of the Rhine basin, Proc. Intern. Conf. on Flood Estimation, Berne, CHR Report II-17 pp 577-585

Merz B, Hall J, Disse M, Schumann A (2010) Fluvial flood risk management in a changing world. Nat Hazards Earth Syst Sci 10:509-527

MMA (2008) Información a cerca del Inventario de Presas con información cartográfica. Ministerio de Medioambiente de España http://www.mma.es/portal/secciones/acm/aguas_continent_zonas_asoc/ seguridad resas/inventario presas/consulta inventario.htm. Accessed 12 December 2009

Neuhold C, Stanzel P, Nachtnebel HP (2009) Incorporating river morphological changes to flood risk assessment: uncertainties, methodology and application. Nat Hazards Earth Syst Sci 9:789-799

Orejana D, Villaseca C, Perez-Soba C, López-García JA, Billström K (2009) The Variscan gabbros from the Spanish Central System: a case for crustal recycling in the sub-continental lithospheric mantle? Lithos $110(1-4): 262-276$

Pall P, Aina T, Stone DA, Stott PA, Nozawa T, Hilberts AMG, Lohmann D, Myles RA (2011) Anthropogenic greenhouse gas contribution to flood risk in England and Wales in autumn 2000. Nature 470:382-385

PATRICOVA (2002) Plan de acción territorial de carácter sectorial sobre prevención del riesgo de inundación en la comunidad valenciana. Documento No 1.Dirección General de Urbanismo y Ordenación Territorial, Generalitat Valenciana, Valencia 
Plate, EJ (2000) Stochastic hydraulic design-Has its time come?. In: Wang Z-Y, Hu S-X. (eds.), Stochastic Hydraulics 2000, Proceedings of the Eighth IAHR Conference on Stochastic Hydraulics, Beijing, Balkema, Rotterdam, pp 3-14

Plate EJ (2002) Flood risk and flood managment. J Hydrol 267:2-11

Rackwitz R, Lentz A, Faber M (2005) Socio-economically sustainable civil engineering infrastructures by optimization. Struct Saf 27:187-229

Rasekh A, Afshar A, Afshar MH (2010) Risk-cost optimization of hydraulic structures: methodology and case study. Water Resour Manag 24(11):2833-2851

Rodrigues AS, Santos MA, Santos AD, Rocha F (2002) Dam-break flood emergency management system. Water Resour Manag 16(6):489-503

Sánchez-Silva M (2001) Basic concepts on risk analysis and the decision making process. Int J Civil Eng Environ Syst 18:225-277

Searcy JK, Hardison CH (1960) Double-mass curves, Manual of hydrology: Part 1. General surface water techniques. United States Government Printing Office, Washington, pp 31-66

Tung T-K (2002) Risk-based design of flood defense systems. In: Wu Y et al (eds) Flood Defence. Scence Press, New York, pp 71-81

Tung YK, Mays LW (1981) Optimal risk-based design of flood levee system. Water Resour Res 17(4):843-852

U.S. Army Corp of Engineers (USACE) (1992) Catalog of residential depth-damage function. IWR Report 92-R-3. Belovoir

U.S. Army Corp of Engineers (USACE) (2009) Hydrologic modelling system HEC-HMS, user's manual. Version 3.4, U.S. Davis, California

Yong KS-K (2005) A numerical model of sediment-laden turbulent flow in an open channel. Can J Civil Eng $32: 233-240$

Zhu T, Lund JR (2009) Up or Out?-Economic-engineering theory of flood levee height and setback. J Water Res Pla-ASCE 135(2):90-95 